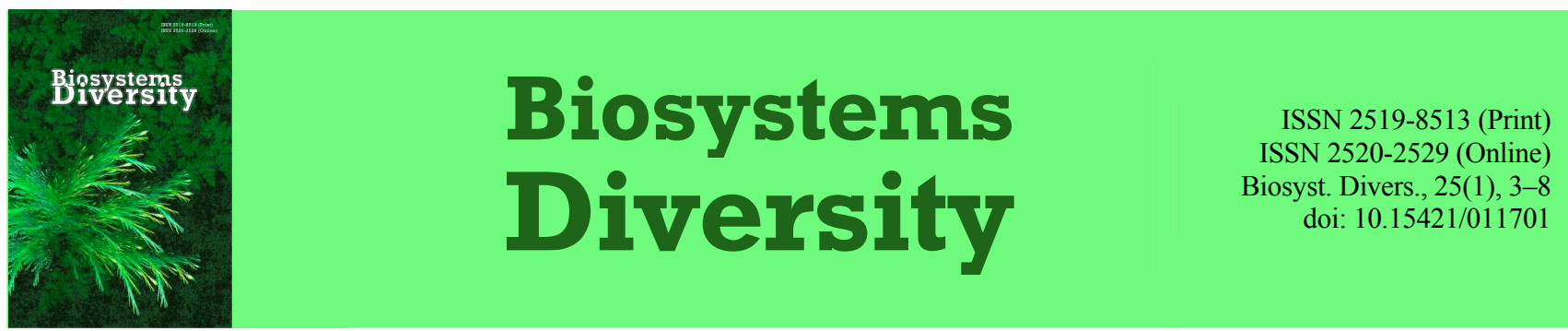

\title{
Seasonal variations in the level of heavy metals in the water of minor rivers
}

\author{
I. L. Sukhodolska \\ Rivne State University of Humanities, Rivne, Ukraine
}

Article info

Received 18.12.2016

Received in revised form 04.01.2017

Accepted 09.01.2017

Rivne State University of Humanities, Stepana Bandery Str., 12, Rivne, 33028, Ukraine

Tel.: +38-098-259-37-57

E-mail:irchukmail@gmail.com

\begin{abstract}
Sukhodolska, I. L. (2017). Seasonal variations in the level of heavy metals in the water of minor rivers. Biosystems Diversity, 25(1), 3-8. doi: 10.15421/011701
\end{abstract}

This article analyses the level of heavy metals ( $\mathrm{Zn}, \mathrm{Mn}, \mathrm{Fe}, \mathrm{Pb}, \mathrm{Co}, \mathrm{Ni}, \mathrm{Cd}$ ) and characteristics of their transportation through the water of minor rivers in Rivne region, Ukraine. The levels of $\mathrm{Zn}, \mathrm{Cu}, \mathrm{Mn}, \mathrm{Fe}, \mathrm{Ni}, \mathrm{Co}$ in the waters of these fisheries exceeded the maximum permissible concentration limit in different months. We found that the concentration of $\mathrm{Pb}$ and $\mathrm{Cd}$ did not exceed the permissible concentration limit in the waters of the fisheries during the year of research, while the level of other metals exceeded the permissible levels by 1.1 to 151.0 times. This research confirms that the surface waters of Rivne region are characterized by high concentrations of iron, manganese, zinc, and nickel. The level of iron exceeded the maximum permissible concentration limit by 1.1 to 5.0 times, the level of zinc by 1.5 to 15.0 times, that of manganese by 1.3 to 6.7 times and the nickel level by 1.3 to 151.0 times in the fishery waters. In principle, the increase in the level of heavy metals $(\mathrm{Zn}, \mathrm{Cu}, \mathrm{Mn}, \mathrm{Fe}, \mathrm{Ni}, \mathrm{Co})$ is connected with the lithological composition of reservoirs in the water-collecting areas of the investigated rivers, and besides with the significant influence of the anthropogenic load (fuel combustion, aqueous wastes of factory units, agricultural effluent, etc.), and with the increase in aquatic vegetation, $\mathrm{pH}$ balance, temperature change and so on. The appearance of iron-manganese compounds can be explained by natural causes such as reformation of the source minerals into secondary minerals in the conditions of $\mathrm{pH}$ level recession in water, which causes the release of these molecular entities; leaching of iron from the iron-manganese septarian nodules, a substantial amount of which is contained in the illuvial horizon. The increase in the level of zinc and nickel in the river water is connected with the leaching of these elements from subsurface rocks, soil and forest leaf litter. Atmospheric condensation is a significant source of the presence of nickel in the surface water. For the investigated rivers, the most significant factors in the water's chemical composition are physiographic (foremost, the character of the soil cover, intensivity of erosion, extent of forest and swamp cover) and anthropogenous impact. In the rivers of Rivne region high concentrations of heavy metals are the consequence of the long-term aggradation of abiotic and biotic substances of the water ecosystem. There is a tendency for a reduction in the concentration of most metals in the abiotic substances of the water reservoir during the vegetative season and an increase after the end of this season. This research shows that the high level of contamination of the water of Rivne region's minor rivers by the investigated heavy metal components is caused primarily by anthropogenic factors.

Keywords: concentration; water ecosystem; pollutants; anthropogenic load

\section{Сезонні зміни вмісту важких металів у воді малих річок}

\section{І. Л. Суходольська}

Рівненський державний гуманітарний університет, Рівне, Україна

Проаналізовано вміст і особливості міграції важких металів ( $\mathrm{Zn}, \mathrm{Mn}, \mathrm{Fe}, \mathrm{Cu}, \mathrm{Pb}, \mathrm{Co}, \mathrm{Ni}, \mathrm{Cd})$ у воді малих річок Рівненщини. Встановлено перевищення гранично допустимих концентрацій для водойм рибогосподарського призначення щодо вмісту $\mathrm{Zn}, \mathrm{Cu}, \mathrm{Mn}, \mathrm{Fe}, \mathrm{Ni}, \mathrm{Co}$ в окремі місяці. Концентрація $\mathrm{Pb}$ та $\mathrm{Cd}$ не перевищує рибогосподарських ГДК упродовж року, тоді як уміст інших металів перевищує норми в 1,1151,0 раза. Поверхневі води Рівненщини характеризуються високими концентраціями феруму, мангану, цинку та нікелю. У першу чергу це пов'язано з літологічним складом порід басейнів досліджуваних річок, а також значним впливом антропогенного навантаження. Надходження сполук феруму та мангану можна пояснити природними причинами: перетворенням первинних мінералів на вторинні за знижених значень $\mathrm{pH}$ води, у результаті чого відбувається вивільнення цих сполук; вимиванням $\mathrm{Fe}$ з ферум-манганієвих конкрецій, значна кількість яких міститься в ілювіальному горизонті грунтів. Збільшенням умісту цинку та нікелю у воді річок пов'язане з вимиванням елементів із гірських порід, грунту та лісової підстилки. Суттєве джерело надходження нікелю у поверхневі води - атмосферні опади. Для досліджених річок найбільш значимі фактори формування хімічного складу води - характер грунтового покриву, інтенсивність ерозійних процесів, а також ступінь лісистості та заболоченості території та антропогенні фактори. Високі концентрації важких металів у річках Рівненщини - наслідок їх тривалої акумуляції в абіотичних та біотичних компонентах гідроекосистеми. Антропогенний чинник - основна причина екстремально високих концентрацій металів у воді річок Рівненщини в окремі періоди.

Ключові слова: концентрація; гідроекосистема; полютанти; антропогенне навантаження 


\section{Вступ}

Природні річкові води - динамічна система, що містить складний комплекс компонентів. Основними джерелами їх привнесення у водні екосистеми та залучення у міграційні потоки вважають природні, кліматичні та біотичні процеси (Aliokhina et al., 2008; Logeshkumaran et al., 2014; Chandra et al., 2015). Важливу роль відіграє також людська діяльність, яка спричинює швидке надходження у поверхневі води полютантів, зокрема, важких металів (BM) (Lim et al., 2012).

Важкі метали - одні 3 найбільш шкодочинних забруднювачів навколишнього середовища, бо, на відміну від забруднювачів органічної природи, вони не розкладаються, а, зазнаючи змін, перерозподіляються між компонентами екосистеми, постійно перебуваючи в ній (Linnik and Zhezheria, 2011; Çelebi et al., 2014; Pandey and Singh, 2015; Brygadyrenko and Ivanyshyn, 2014, 2015; Kul'bachko et al., 2015; Tsvetkova et al., 2016). Найчастіше розрізняють розчинну, завислу та седиментовану форми металів, стабільність яких значною мірою залежить від інтенсивності перебігу процесів, що відбуваються у водному середовищі та донних відкладеннях того чи іншого водного об'єкта, насамперед гідролізу, комплексоутворення, адсорбції та осадження (Linnik, 2000). Вказані процеси визначають міграційну рухливість важких металів, перерозподіл між основними компонентами водної екосистеми, біодоступність і токсичність для водних організмів (Fufeyin and Egborge, 1998; Linnik et al., 2012; Abdel-Khalek et al., 2016).

Біологічна небезпечність металів визначається також тим, що вони зазнають модулювального впливу температури, $\mathrm{pH}$ середовища, вмісту кисню, присутності хелатувальних агентів та низки інших чинників (Grubinko et al., 2011). Одночасно сполуки важких металів відіграють важливу роль у життєдіяльності всіх організмів, оскільки у невеликих кількостях проявляють високу фізіологічну активність та виконують роль активаторів біохімічних та фізіологічних процесів (Elkady et al., 2015; Bukar et al., 2016; Prokopchuk and Grubinko, 2016). Збільшення їх природних концентрацій зумовлює токсичний вплив на живі організми (Bruins et al., 2000; Dragun et al., 2009). Як результат важкі метали спричинюють мутагенний і тератогенний ефекти, проявляють синергізм, посилюючи дію інших токсикантів на біоту (Sudha et al., 2013; Klymenko et al., 2016). Хімічний склад природних водойм неоднорідний, а специифічність геохімічних процесів зумовлюе різноманіття співіснуючих форм важких металів і певні закономірності їх міграції у водному середовищі (Lomniczi et al., 2007; Reza and Singh, 2010; Chandra et al., 2015). 3 огляду на зазначене вище мета цього дослідження - визначити ступінь забруднення води мАлих річок Рівненщини важкими металами ( $\mathrm{Zn}, \mathrm{Mn}, \mathrm{Fe}, \mathrm{Cu}, \mathrm{Pb}$, $\mathrm{Co}, \mathrm{Ni}, \mathrm{Cd}$ ) залежно від рівня антропогенного навантаження на типу гідроекосистеми.

\section{Матеріал і методи досліджень}

Під час дослідження у складі Рівненської області виділено чотири типи територій, що відрізняються рівнем антропогенного навантаження: рекреаційна (5150’06.0"N, 2609'10.8"Е), аграрна $\left(50^{\circ} 27^{\prime} 17.3^{\prime \prime} \mathrm{N}, 25^{\circ} 42^{\prime} 14.9^{\prime \prime} \mathrm{E}\right)$, урбанізована $\left(50^{\circ} 37^{\prime} 28.6^{\prime \prime} \mathrm{N}\right.$, $\left.26^{\circ} 14^{\prime} 27.8^{\prime \prime} \mathrm{)}\right)$ та техногенно трансформована $\left(50^{\circ} 37^{\prime} 28.6^{\prime \prime} \mathrm{N}\right.$, $26^{\circ} 14^{\prime} 27.8^{\prime \prime}$ ). До рекреаційної території віднесено Зарічненський район, оскільки у ньому розташований важливий об'єкт природно-заповідного фонду Рівненщини - регіональний ландшафтний парк «Прип'ять-Стохід». На даній території досліджували річку Простир. За аграрну територію обрано один із розораних південних районів області - Дубенський. Досліджували річку Іква. Як урбанізовану територію аналізували місто Рівне, як техногенно трансформовану - Здолбунівський район, в якому зосереджено найбільші підприємства Рівненщини (ТОВ «Укрцемремонт» і ВАТ «Здолбунівський механічний завод»). На цих територіях досліджено річку Устя (рис. 1).
Проаналізовано 288 проб води річок Рівненщини, відібраних упродовж квітня - грудня 2012 р. та січня - березня 2013 р. Зразки води відібрано за різними створами Рівненщини відповідно до рівня антропогенного навантаження території. У кожному створі у 6 точках щомісячно відбирали по 6 проб. Проби води відбирали із середини річки, 3 поверхневого горизонту, із глибини 0,5-0,7 м за допомогою пластикових пробовідбірників об'ємом 1 л. Воду фільтрували через мембранний фільтр із діаметром пор 0,45 мкм, концентрували у 10 разів та визначали вміст ВМ методом атомно-абсорбційної спектрофотометрії на спектрофотометрі C-115 M1 за відповідної довжини хвилі, яка відповідала максимуму поглинання кожного $з$ досліджуваних металів згідно зі стандартними методиками (Novikov et al., 1990). Концентрацію (С) металів виражали в мг/л досліджуваних зразків.

\section{Результати та їх обговорення}

Для малих річок Рівненщини найбільш значимі фактори формування хімічного складу води - фізико-географічні, насамперед, характер грунтового покриву та інтенсивність ерозійних процесів, ступінь лісистості та заболоченості території, а також антропогенні. Порівняння середнього вмісту ВМ у воді малих річок Рівненщини з різним рівнем антропогенного навантаження наведено на рисунках 2 та 3.

Цинк. У водоймі рекреаційної території вміст Zn протягом квітня - травня низький, але вже у серпні та вересні суттєво підвищився до 0,15 і 0,07 мг/л, що в 15 та 7 разів перевищило норму ГДК (ГДК $(\mathrm{Zn})$ рибгосп. $=0,01$ мг/л). У наступні місяці виявлено лише сліди $\mathrm{Zn}$. Вміст Zn у водоймі урбанізованої території різко збільшився у вересні, що перевищило норму ГДКрибгосп. у 7 разів, протягом наступних місяців перевищень не спостерігали. Концентрація Zn у водоймі аграрної території незмінна протягом квітня - серпня, а в осінній період варіювала від 0,0005 до 0,0017 мг/л. У водоймі техногенно трансформованої території вміст Zn від початку спостереження до вересня не змінювався. Концентрація $\mathrm{Zn}$ у воді малих річок Рівненщини різко збільшилася та перевищила ГДКрибгосп. у 1,5 раза у вересні, а протягом наступних місяців зменшувалася.

Оскільки цинк - есенціальний метал, можна передбачити його активне засвоєння фітогідробіонтами, у клітинах яких іони цинку беруть участь у ключових реакціях фотосинтезу, 3 чим можна пов'язати зменшення вмісту металу у воді 3 настанням вегетаційного періоду. Унаслідок відмирання восени водних рослин концентрація цинку знову збільшується. У воді цинк перебуває в іонній формі або у формі мінеральних та органічних комплексів. Іноді зустрічається в нерозчинній формі у вигляді гідроксиду, карбонату, сульфіду тощо. Цинк належить до групи малопоширених елементів. Згідно $з$ літературними даними, близько $90 \%$ його кількості у водних екосистемах пов'язано з антропогенною діяльністю. Значна кількість цинку переноситься та випадає разом 3 атмосферними опадами, концентрація може досягати 0,008-0,330 мг/л (Chen et al., 2007). Також цинк надходить у поверхневі води зі стоком гальванічних цехів машинобудівної та електротехнічної промисловості, целюлозно-паперових підприємств, заводів міндобрив. Токсичність цинку зумовлюється антагонізмом 3 іншими важкими металами (Dong et al., 2012; Linnik et al., 2012).

Манган. У водоймі рекреаційної території перевищення норми ГДКрибгосп. щодо вмісту $\mathrm{Mn}$ у воді зафіксоване у вересні (2,8 раза), листопаді (1,3 раза) та січні (1,4 раза) (ГДК(Mn)рибгосп. $=0,01$ мг/л). Протягом наступних місяців виявлено лише сліди мангану. У водоймі урбанізованої території вміст Mn у квітні незначний, а у травні його концентрація різко збільшилася та перевищила норму ГДКрибгосп. в 1,7 раза. В наступні місяці спостерігали суттєве зменшення концентрації Mn: у листопаді перевищення у 1,4 раза, у січні - у 4 раза. Щодо вмісту $\mathrm{Mn}$ у річковій воді аграрної території, то у квітні виявлено лише його сліди, у травні вміст 
підвищився та перевищив ГДКрибгосп. в 1,4 раза, в листопаді1,3 раза, січні - у 6,7 раза. Протягом наступних місяців вміст $\mathrm{Mn}$ був незначним. Перевищення вмісту ГДКрибгосп. Mn у водоймі техногногенно трансформованої території, як і на решті територій, зафіксовано в листопаді (1,4 раза) та січні (5,8 раза). Концентрація мангану у поверхневих водах схильна до сезонних коливань. Факторами, що визначають зміни концентрацій мангану, є співвідношення між поверхневим та підземним стоками, інтенсивність споживання при фотосинтезі, розкладання фітопланктону, мікроорганізмів та вищої водної рослинності, а також процеси осадження його на дно водойм (Fedonenko et al., 2016). Крім того, на вміст мікроелементів у поверхневих водах значно впливають ступінь заболоченості і залісненості їх басейну, а також характер грунтового покриву. Чим більше заболочений чи заліснений басейн, тим більше у воді річок міститься мангану та цинку, що зумовлено високим вмістом цих елементів у лісовій підстилці та торфах (Volesky and Holan, 1995; Bhutiani et al., 2016).

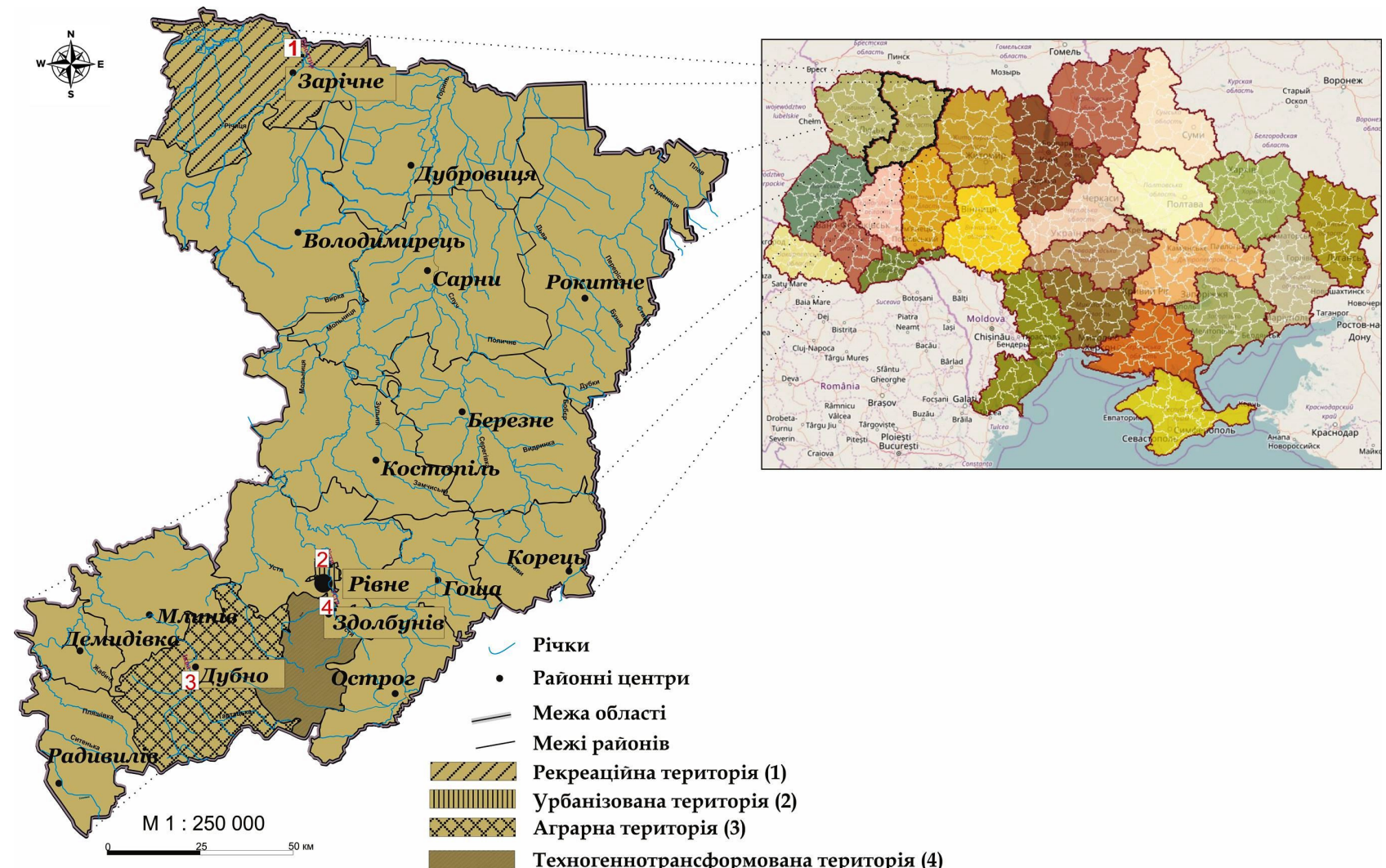

Рис. 1. Картосхема територій досліджуваних річок і точки відбору проб ( $\mathrm{M} \pm \mathrm{m} ; \mathrm{n}=6): 1$ - рекреаційна територія (р. Простир); 2 - урбанізована територія (р. Устя); 3 - аграрна територія (р. Іква); 4 - техногенно трансформована (р. Устя)
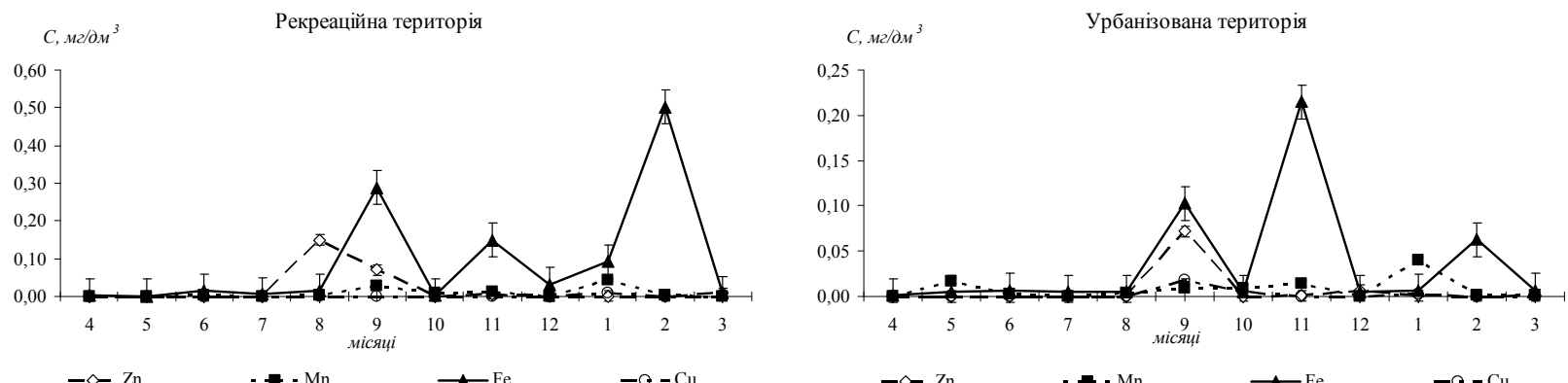

$a$
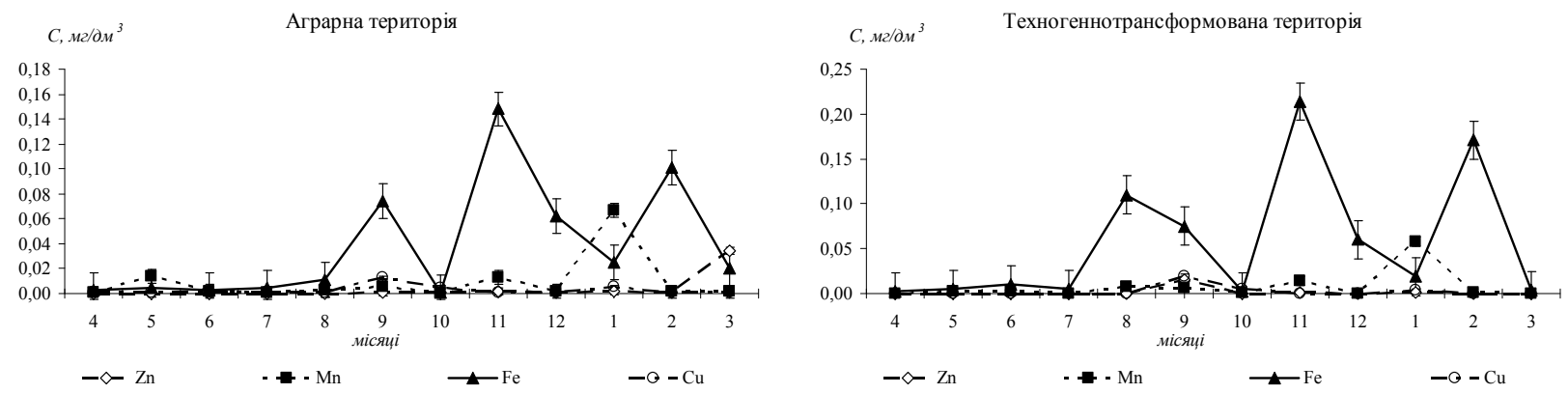

Рис. 2. Вміст есенціальних важких металів у воді річок Рівненщини (квітень - грудень 2012, січень - березень 2013 p., $\mathrm{M} \pm \mathrm{m}, \mathrm{n}=6$ ): $a$ - рекреаційна, $\sigma$ - урбанізована, 8 - аграрна, 2 - техногенно трансформована 
Ферум. Вміст феруму у річці рекреаційної території перевищив ГДКрибгосп. у вересні (2,8 раза), листопаді (1,5 раза) та лютому (5,0 раза) $($ ГДК(Fе)рибгосп. $=0,1$ мг/л). У водоймі урбанізованої території вміст феруму протягом усіх дослідних місяців незначний (крім листопада - перевищення ГДКрибгосп. у 2,2 раза). Вміст феруму у річці аграрної території перевищив норму ГДКрибгосп. у листопаді та лютому. У водоймі техногенно трансформованої території перевищення ГДКрибгосп. спостерігали у серпні (1,1 раза), листопаді (2,1 раза) та лютому (1,7 раза). Ферум характеризується значною міграційною рухливістю, особливо за зменшення $\mathrm{pH}$ води. Разом із тим частина феруму може міститись у складі комплексних сполук, i його перехід із донних відкладів у воду та навпаки лімітується, оскільки залежить від інтенсивності міграції органічних речовин, з якими метал зв'язаний у комплекси (Linnik et al., 2012).

Динаміка вмісту феруму у дослідних компонентах водойми значно нагадує таку для мангану, адже ці елементи близькі як за фізико-хімічними властивостями, так і за відношенням до біоти. Разом із тим, загальний вміст мангану порівняно з ферумом у воді, хоча і не значно, але вищий. Загальна концентрація та форми сполук феруму у водних екосистемах залежать від геологічних особливостей водозбірної площі, характеру водообміну та

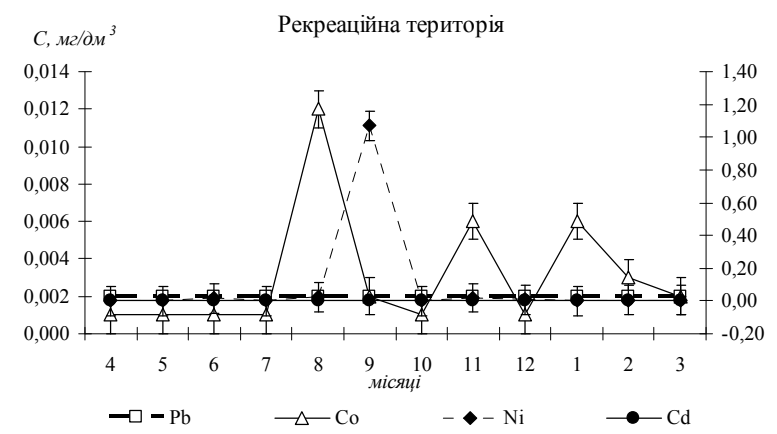

$a$

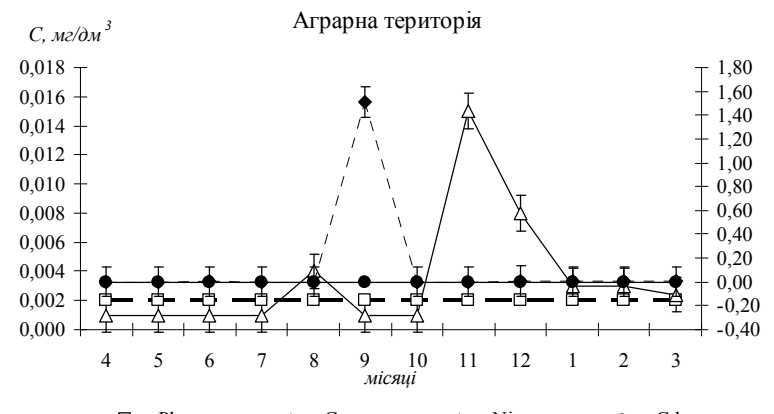

B

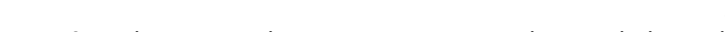

Рис. 3. Вміст неесенціальних важких металів у воді річок Рівненщини (квітень - грудень 2012, січень - березень 2013 р., $\mathrm{M} \pm \mathrm{m}, \mathrm{n}=6)$ : позначення див. рис. 2

Купрум. У водоймі рекреаційної території протягом усього періоду дослідження концентрація Сu виявлена на рівні слідових кількостей. У водоймі урбанізованої території вміст $\mathrm{Cu}$ суттєво не змінювався протягом періоду дослідження, лише у вересні спостерігали перевищення ГДКрибгосп. у 1,7 раза (ГДК(Сu)рибгосп. =0,001-0,01 мг/л). У річках аграрної, урбанізованої та техногенно трансформованої територій перевищення ГДКрибгосп. зафіксоване у 1,3, 1,7 та 1,9 раза у вересні. У вересні внаслідок відмирання фітомаси концентрація купруму у воді збільшується шляхом його надходження 3 водних організмів. У наступні місяці відбувається утворення комплексних сполук $\mathrm{Cu}$ з розчиненими органічними речовинами, вміст яких зростає також у зв'язку з відмиранням гідробіонтів. Наслідок цього - зменшення концентрації $\mathrm{Cu}$. За присутності хелатів, гумінових кислот, завислих речовин концентрації купруму знижуються в 1,0-1,5 раза (Dragun et al., 2009). $\mathrm{У}$ природних умовах $\mathrm{Cu}$ широко трапляється у самородному кількості опадів (Romanenko, 2001; Kim et al., 2010; Abdel-Khalek et al., 2016). Ферум потрапляе у водойми з відходами підприємств різних галузей промисловості, сільського господарства та 3 дренажними водами меліоративних систем (Lim et al., 2012). Найчастіше джерела забруднення поверхневих водойм сполуками $\mathrm{Fe}$ - підприємства машинобудівної та металообробної промисловості, а також шахтне та рудне виробництва.

Для дослідних водних об'єктів такі джерела забруднення не характерні. Тому надходження сполук феруму можна пояснити природними причинами: перетворенням первинних мінералів на вторинні за знижених значень $\mathrm{pH}$ води, у результаті чого відбувається вивільнення цих сполук; вимиванням $\mathrm{Fe}$ iз ферум-манганієвих конкрецій, значна кількість яких міститься в ілювіальному горизонті дерново-підзолистих грунтів, якими частково представлена рекреаційна територія.

Природні джерела надходження іонів Fе у водойми - процеси вивітрювання гірських порід, які супроводжуються їх механічним руйнуванням і розчиненням. Унаслідок взаємодії з мінеральними та органічним речовинами, які містяться у природних водах, в останніх утворюються складні комплекси сполук феруму, що перебувають у воді в розчиненому, колоїдному та завислому станах (Linnik et al., 2012; Li et al., 2015).

6
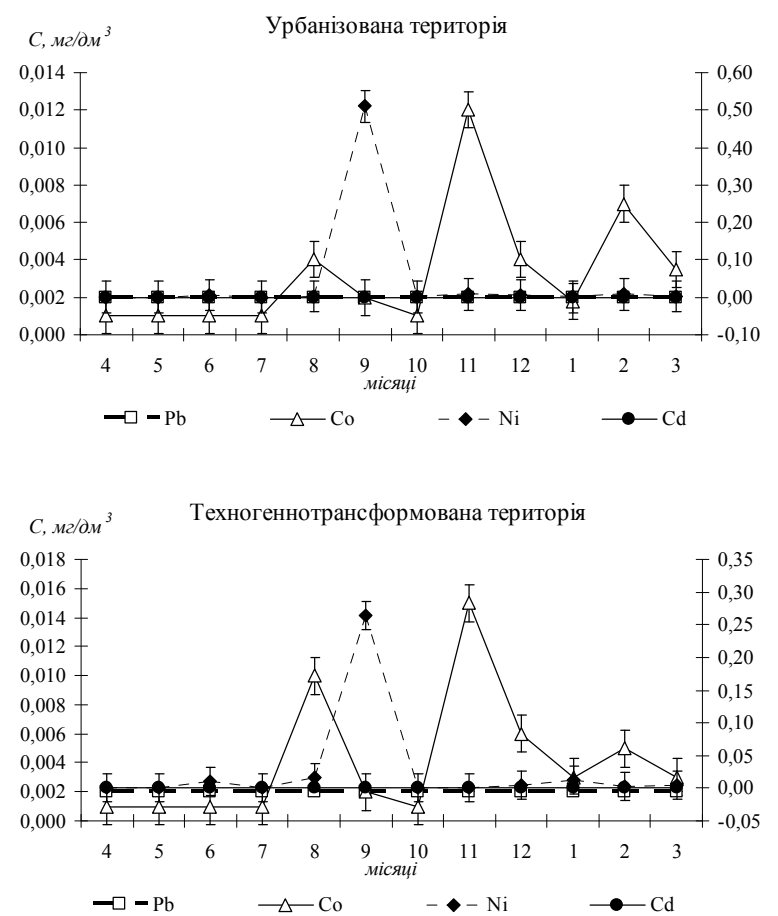

стані та у вигляді сульфідів, арсенідів, хлоридів тощо. Одне із джерел забруднення іонами цього металу - скидання неочищених стоків підприємств, відходи хімічної промисловості та сільськогосподарські добрива (Chen et al., 2012; Bhutiani et al., 2016).

Плюмбум. Щодо вмісту $\mathrm{Pb}$ у воді, на всіх територіях виявлено лише його сліди (ГДК(Рb)рибгосп. $=0,01$ мг/л), оскільки плюмбум може легко вступати у реакції з головними макрокомпонентами поверхневих водойм і утворювати важкорозчинні сполуки. Плюмбум належить до малопоширених елементів, тому його присутність у поверхневих водах зумовлена широким використанням сполук $\mathrm{Pb}$ у промисловості. Значна кількість плюмбуму потрапляе у річкові води внаслідок спалювання вугілля, зі стічними водами металургійної та хімічної промисловості (Kim et al., 2010; Linnik et al., 2012). Сполуки $\mathrm{Pb}$ потрапляють у навколишнє середовище разом з аерозольними частинками викидів промислових підприємств, з використаними промисловими водами, під час спалювання нафтопродук- 
тів. Особливості розподілу та міграції Рb зумовлені інтенсивністю осадження та комплексоутворення. Значна кількість $\mathrm{Pb}$ потрапляє у водні екосистеми у складі автомобільних викидів (Romanenko, 2001; Reza and Singh, 2010; Linnik et al., 2012).

Кобальт. Вміст Со перевищив норму ГДКрибгосп. у водоймі рекреаційної території у серпні, урбанізованої території у листопаді у 1,2 раза (ГДК(Со)рибгосп. $=0,01$ мг/л). У водоймі аграрної та техногенно трансформованої територій вміст кобальту перевищив норму ГДКрибгосп. у листопаді в 1,5 раза. Зростання вмісту кобальту у воді в листопаді зумовлене великою кількістю опадів у цей час, унаслідок чого метал у річку потрапляє 3 дощовими водами. Зменшення концентрації Со у вегетаційний період пояснюється його утилізацією гідробіонтами. У природні води сполуки кобальту надходять у результаті процесів вилуження з мідно-колчеданових та інших руд, із грунтів під час розкладання решток рослинних і тваринних організмів, а також зі стічними водами металургійних, металообробних і хімічних заводів (Linnik et al., 2012; Abdel-Khalek et al., 2016).

Нікель. У водоймі рекреаційної території концентрація Ni перевищила норму ГДКрибгосп. у червні в 1,6 раза, у серпні у 2,3 раза, у вересні - у 107 раза, у листопаді - в 1,7 раза (ГДК(Ni)рибгосп. $=0,01$ мг/л). Вміст Ni у водоймах урбанізованої та аграрної територій перевищив норми ГДКрибгосп. протягом вересня у 51 та 151 раз. Концентрація нікелю у водоймі техногенно трансформованої території перевищила норму ГДКрибгосп. у червні - в 1,1 раза, у серпні - в 1,6 раза, вересні - в 26 разів та у січні - в 1,3 раза. Флуктуаційна динаміка вмісту нікелю у воді може бути пов'язана 3 невисоким ступенем його закомплексованості, оскільки в умовах досліджених природних вод існує конкурентне зв'язування фульвокислот іншими металами, серед яких найбільший вклад в утворення комплексних сполук вносять ферум і купрум (Linnik et al., 2012). Уміст нікелю у природних водах визначається складом порід, крізь які проходить вода. Може потрапляти у водойми із грунтів, у результаті розкладання відмерлих рослинних і тваринних організмів, а також зі стічними водами цехів нікелювання, заводів синтетичного каучуку, нікелевих збагачувальних фабрик і з атмосферними опадами (Ptashynski and Klaverkamp, 2002; Cavani, 2005; Borbely and Nagy, 2009).

Кадмій. У водоймах усіх досліджуваних територій виявлено лише сліди Сd (ГДК(Сd)рибгосп. = 0,005 мг/л). Іони кадмію потрапляють у природні води під час вилужування грунтів, поліметалічних, мідних руд, у результаті розкладання відмерлих гідробіонтів, здатних його накопичувати. Також сполуки кадмію виносяться у водойми зі стічними водами заводів, деяких хімічних підприємств (виробництво сульфатної кислоти), гальванічного виробництва, рудозбагачувальних фабрик і з шахтними водами (Volesky and Holan, 1995; Fedonenko et al., 2016). Інтенсивне ведення сільського господарства (застосування мінеральних добрив і пестицидів, використання стічних вод для іригаційних робіт), нагромадження та спалювання побутових відходів - ці процеси також спричинюють забруднення сполуками кадмію (Klimas, 1995; Godt et al., 2006). Зниження концентрації розчинених сполук кадмію відбувається унаслідок сорбції, випадання в осад гідроксиду та карбонату кадмію та їх споживання водними організмами (Volesky and Holan, 1995; Yang et al., 1995). Токсичність кадмію у воді залежить від наявності інших речовин, з якими він може утворювати комплексні сполуки. При комплексоутворенні 3 органічними речовинами, зокрема, 3 гуміновими та фульвокислотами, його токсичність різко знижується (Romanenko, 2001; Linnik et al., 2012).

\section{Висновки}

Якість води у малих річках Рівненщини за вмістом важких металів ( $\mathrm{Zn}, \mathrm{Cu}, \mathrm{Mn}, \mathrm{Fe}, \mathrm{Ni}, \mathrm{Co})$ не відповідає допустимим рівням, за винятком $\mathrm{Pb}$ та $\mathrm{Cd}$, концентрація яких не перевищує гранично допустимих концентрацій для рибогосподарських водойм. Простежується спільна для більшості металів тенденція до зниження їх вмісту протягом вегетаційного періоду та зростання після його закінчення. Підвищений вміст $\mathrm{Mn}$ i Fe у воді річок може бути зумовлений вимиванням цих елементів із ферум-манганієвих конкрецій грунту та $з$ лісової підстилки. Найбільш несприятлива ситуація спостерігається у поверхневих водах усіх досліджених територій щодо вмісту $\mathrm{Ni}$. Зростання вмісту Ni у поверхневих водах може бути пов'язане 3 великою кількістю опадів, що спостерігали у серпні та вересні, а також акумуляцією його сполук в інших компонентах середовища 3 подальшим надходженням у водойми. Загалом екологічний стан досліджуваних річок залишається незадовільним.

\section{References}

Abdel-Khalek, A. A., Elhaddad, E., Mamdouh, S., \& Marie, M. A. (2016). Assessment of metal pollution around sabal drainage in River Nile and its impacts on bioaccumulation level, metals correlation and human risk hazard using Oreochromis niloticus as a bioindicator. Turkish Journal of Fisheries and Aquatic Sciences, 16, 227-239.

Aliokhina, T. M., Bobko, A. O., \& Malakhov, I. M. (2008). Content of the heavy metals in water and bottom sediments of the Ingulets River. Hydrobiological Journal, 44(5), 105-110.

Bhutiani, R., Khanna, D. R., Kulkarni, D. B., \& Ruhela, M. (2016). Assessment of Ganga River ecosystem at Haridwar, Uttarakhand, India with reference to water quality indices. Applied Water Science, 6(2), 107-113.

Borbely, G., \& Nagy, E. (2009). Removal of zinc and nickel ions by complexation-membrane filtration process from industrial wastewater. Desalination, 240(1-3), 218-226.

Bruins, M. R., Kapil, S., \& Oehme, F. W. (2000). Microbial resistance to metals in the environment. Ecotoxicology and Environmental Safety, 45(3), 198-207.

Brygadyrenko, V. V., \& Ivanyshin, V. M. (2014). Impact of ferric salt on body weight of Megaphyllum kievense (Diplopoda, Julidae) and litter granulometric composition in the laboratory experiment. Visnyk of Dnipropetrovsk University. Biology, Ecology, 22(1), 83-87.

Brygadyrenko, V. V., \& Ivanyshyn, V. (2015). Changes in the body mass of Megaphyllum kievense (Diplopoda, Julidae) and the granulometric composition of leaf litter subject to different concentrations of copper. Journal of Forest Science, 61(9), 369-376.

Bukar, P. H., Oladipo, M. O. A., Ibeanu, I. G. E., \& Zakari, I. Y. (2016). Assessment and distribution of metal pollutants in the water of River Ngadda and Alau Dam used for irrigation farming in Maiduguri, Borno State, Nigeria. American Journal of Research Communication, 4(4), 74-84.

Cavani, A. (2005). Breaking tolerance to nickel. Toxicology, 209(2), 119-121.

Çelebi, A., Şengörür, B., \& Kløve, B. (2014). Seasonal and spatial variations of metals in Melen Watershed Groundwater, Turkey. CLEAN - Soil, Air, Water, 43(5), 739-745.

Chandra, S., Singh, P. K., Tiwari, A. K., Panigrahy, B., \& Kumar, A. (2015). Evaluation of hydrogeological factor and their relationship with seasonal water table fluctuation in Dhanbad district, Jharkhand, India. ISH Journal of Hydraulic Engineering, 21(2), 1-14.

Chen, C. W., Chen, C. F., \& Dong, C. D. (2012). Copper contamination in the sediments of Salt River Mouth, Taiwan. International Conference on Future Energy, Environment, and Materials, 16, 901-906.

Chen, C. W., Kao, C. M., Chen, C. F., \& Dong, C. D. (2007). Distribution and accumulation of heavy metals in the sediments of Kaohsiung Harbor, Taiwan. Chemosphere, 66(6), 1431-1440.

Dong, C. D., Chen, C. F., \& Chen, C. W. (2012). Contamination of zinc in sediments at River Mouths and Channel in Northern Kaohsiung Harbor, Taiwan. International Journal of Environmental Science and Development, 3(6), 517-521.

Dragun, Z., Roje, V., Mikac, N., \& Raspor, B. (2009). Preliminary assessment of total dissolved trace metal concentrations in Sava River water. Environmental Monitoring and Assessment, 159(1-4), 99-110.

Elkady, A. A., Sweet, S. T., Wade, T. L., \& Klein, A. G. (2015). Distribution and assessment of heavy metals in the aquatic environment of Lake Manzala, Egypt. Ecological Indicators, 58, 445- 457.

Fedonenko, O., Yesipova, N., \& Sharamok, T. (2016). The accumulation of heavy metals and cytometric characteristics features of red blood cells in different ages of carp fish from Zaporozhian Reservoir. International Letters of Natural Sciences, 53, 72-79.

Fufeyin, T. P., \& Egborge, A. B. M. (1998). Heavy metals of Ikpoba River, Benin, Nigeria. Tropical Freshwater Biology, 7, 27-36. 
Godt, J., Scheidig, F., Grosse-Siestrup, C., Esche, V., Brandenburg, P., Reich, A., \& Groneberg, D. (2006). The toxicity of cadmium and resulting hazards for human health. Journal of Occupational Medicine and Toxicology, 1, 22-30.

Grubinko, V. V., Gorda, A. I., Bodnar, O. I., \& Klochenko, P. D. (2011) Metabolism of algae under the impact of metal ions of the aquatic medium (a review). Hydrobiological Journal, 47(6), 75-88.

Kim, Y., Kim, B. K., \& Kim, K. (2010). Distribution and speciation of heavy metals and their sources in Kumbo River sediments Korea. Environment Earth Science, 60(5), 943-942.

Klimas, A. A. (1995). Impacts of urbanization and protection of water resources in the Vilnius District, Lithuania. Hydrobiological Journal, 3(1), 24-35.

Klymenko, M. O., Pylypenko, J. V., \& Bjedunkova, O. O. (2016). Ogljad pidhodiv do ocinjuvannja zdorov'ja gidroekosystem za pokaznykamy gomeostazu ryb [Health assessment of hydro-ecosystems based on homeostasis indicators of fish: Review of approaches]. Visnyk of Dnipropetrovsk University. Biology, Ecology, 24(1), 61-71 (in Ukrainian).

Kul'bachko, Y. L., Didur, O. O., Loza, I. M., Pakhomov, O. E., \& Bezrodnova, O. V. (2015). Environmental aspects of the effect of earthworm (Lumbricidae, Oligochaeta) tropho-metabolic activity on the $\mathrm{pH}$ buffering capacity of remediated soil (steppe zone, Ukraine). Biology Bulletin, 42, 899-904.

Li, P., Qian, H., Howard, K. W. F., \& Wu, J. (2015). Heavy metal contamination of Yellow River alluvial sediments, Northwest China. Environmental Earth Sciences, 73(7), 3403-3415.

Lim, W. Y., Aris, A. Z., \& Zakaria, M. P. (2012). Spatial variability of metals in surface water and sediment in the Langat River and geochemical factors that influence their water-sediment interactions. The Scientific World Journal, 39, 1-14.

Linnik, P. N. (2000). Heavy metals in surface waters of Ukraine: Their content and forms of migration. Hydrobiological Journal, 36(3), 31-54.

Linnik, P. N., Zhezherya, V. A., \& Zubenko, I. B. (2012). Content of metals and forms of their migration in the water of the rivers of the Pripyat River Basin. Hydrobiological Journal, 48(2), 85-101.

Linnik, P., \& Zhezherya, V. (2011). Peculiarities of metals migration in the "bottom sediments - water" system with decreasing $\mathrm{pH}$ and increasing the concentration of fulvic acids. Hydrobiological Journal, 47(5), 86-101.

Logeshkumaran, A., Magesh, N. S., Godson, P. S., \& Chandrasekar, N. (2014). Hydro-geochemistry and application of water quality index (WQI) for groundwater quality assessment, Anna Nagar, part of Chennai City, Tamil Nadu, India. Applied Water Science, 5(4), 335-343.
Lomniczi, I., Boemo, A., \& Musso, H. (2007). Location and characterisation of pollution sites by principal component analysis of trace contaminants in a slightly polluted seasonal river: A case study of the Arenales River (Salta, Argentina). Water SA, 3(4), 479-485.

Novikov, Y., Lastochkina, K., \& Boldina, Z. (1990). Metody isledovania kachestva vody vodoemov [Research methods of water quality of water basins]. Meditsyna, Moscow (in Russian).

Pandey, J., \& Singh, R. (2015). Heavy metals in sediments of Ganga River: up- and downstream urban influences. Applied Water Science, 5, 1-10.

Prokopchuk, O. I., \& Grubinko, V. V. (2016). Vazhki metaly u malyh richkah Ternopil'shhyny z riznym rivnem antropichnogo navantazhennja [Heavy metals in the small rivers of Ternopil region under different types of anthropogenic pressure]. Visnyk of Dnipropetrovsk University. Biology, Ecology, 24(1), 173-181 (in Ukrainian).

Ptashynski, M. D., \& Klaverkamp, J. F. (2002). Accumulation and distribution of dietary nickel in lake whitefish (Coregonus clupeaformis). Aquatic Toxicology, 58, 249-264.

Reza, R., \& Singh, G. (2010). Heavy metal contamination and its indexing approach for river water. International Journal of Environmental Science \& Technology, 7(4), 785-792.

Romanenko, V. (2001). Osnovy hidroekolohii [Basics of hydroecology]. Oberehy, Kyiv (in Ukrainian).

Sudha, C. M., Ravichandran, S., \& Sakthivadivel, R. (2013). Water bodies protection index for assessing the sustainability status of lakes under the influence of urbanization: A case study of south Chennai, India. Environment, Development and Sustainability, 15(5), 1157-1171.

Tsvetkova, N. M., Pakhomov, O. Y., Serdyuk, S. M., \& Yakyba, M. S. (2016). Biologichne riznomanittja Ukrajiny. Dnipropetrovs'ka oblast'. Grunty. Metaly u gruntah [Biological diversity of Ukraine. The Dnipropetrovsk region. Soils. Metalls in the soils]. Lira, Dnipropetrovsk (in Ukrainian).

Volesky, Z. R., \& Holan, A. (1995). Biosorption of heavy metals. Biotechnol. Progress, 11, 235-250.

Yang, X. E., Baligar, V. C., Martens, D. C., \& Clark, R. B. (1995). Influx, transport and accumulation of cadmium in plant species grown at different $\mathrm{Cd}^{2+}$ activities. Environmental Journal of Environmental Science and Health, 30, 569-583. 